\title{
Research on the Introduction of High-quality Education Resources in Chinese-foreign Cooperative Programs
}

\author{
Haiying $\mathrm{Ma}^{1, \mathrm{a}^{*}}$ and Rangjia Cai ${ }^{2, \mathrm{~b}}$ \\ ${ }^{1,2}$ School of Economics, Northwest Minzu University, Lanzhou (730124), P.R.China \\ alxmahaiying8888@163.com, b522766108 @qq.com
}

\begin{abstract}
Keywords: Higher education; Chinese-foreign cooperative program; Excellent education resources; Education communication and cooperative
\end{abstract}

\begin{abstract}
In the Chinese-foreign cooperative program, the introduction of high quality education resources must adhere to is beneficial to the students' growth and development, beneficial to the improvement of the school ability construction and the overall level, is advantageous to the national economic and social development, promote the regional development of the principle of balance and harmony. To establish and perfect the work mechanism of Chinese-foreign cooperative program, to adjust the import high quality teaching resource strategic layout, formulate management policies and measures to explore the new way of cooperative program, strengthen cooperative program actively, establish overall coordination mechanism of high quality education resources are introduced, at the same time to strengthen the financial and capital investment, create a good social environment and atmosphere, Chinese-foreign cooperative program with high quality talent team construction, strengthen the theoretical research of Chinese-foreign cooperative program.
\end{abstract}

\section{Introduction}

It is an important way to enhance the internationalization level of education in China by expanding education opening and carrying out education communication and cooperative in a multi-level and wide area. Chinese-foreign cooperative program play an active role in promoting the innovation of school management system mechanism and reform of personnel training mode, as well as promoting the construction of high level universities. The introduction of foreign high-quality education resources is the decisive factor for the core and successful business success of Chinese-foreign cooperative program. But, overall, the current through the Chinese-foreign cooperative program to introduce the foreign education resources quantity and quality, and the national reform and opening up and the needs of the education internationalization of Chinese-foreign cooperative program of Chinese-foreign cooperative program and society doesn't fit the new expectation and place. In order to make the Chinese-foreign cooperative program and the introduction of high quality education resources to realize sustainable development, must accurately grasp the connotation of foreign high-quality education resources characteristics and significance of Chinese-foreign cooperative program, to guide whether high quality education resources as the highest standards of evaluation of Chinese-foreign cooperative program, promote the development of ideas, thinking of the profound change; We should set up the whole process management concept of high-quality education resources rationally introducing and effectively utilizing, respecting the objective laws and acting according to laws; Establish and perfect the long-acting mechanism that leads to the excellent education resources, and actively construct the supporting system on which this mechanism depends.

\section{The Connotation, Characteristics and Principles of Cooperative Education Resources}

Connotation and Characteristics of Foreign Education Resources. Foreign high-quality education resources refers to the worldwide with high level and characteristics of running a school, has a certain advantage of education teaching idea, training mode, curriculum, textbooks, teaching methods, education management system, teaching staff, the management team and quality guarantee system, etc. 
In the higher education field, the foreign education resources in foreign countries are usually characterized by distinctive or existing disciplines and majors. Introduce foreign high-quality education resources with diversity, practicability, complementarities and procedural characteristics, these characteristics reflect the unity of the relativity and absoluteness, in the concrete of a Chinese-foreign cooperatively-run school, project, in the process of administrative examination and approval and supervision should firmly grasp this important features. In the field of higher education, around the Chinese-foreign cooperative program should focus on how to promote the construction of a world-class university and the construction of local and special type of high-level university, give full play to the Chinese-foreign cooperative program in the subject construction and talents training mode reform of institutions of higher learning, and the role of institutions of higher learning management system and mechanism innovation.

Diversity Characteristics. In the field of higher education, quality education resources, not only refers to the foreign first-class university, the first-class discipline, also can be a feature of professional institutions abroad, with high quality courses, as well as the high level teachers associated with it. The comprehensive ranking of world universities can be used as a reference for judging the advantages and disadvantages of education resources. High quality education resources, however, the standard is not ranking as the only option, for example, there may be a general subject to a famous university or a professional, and a generally ranked university one or a few is likely to be discipline or professional characteristics, impact and high quality. Education resources in western developed countries are more advanced. The majority of developed countries should change the concept of developed countries and sorrow, the bold exploration of moderately developed countries and developing countries to introduce the possibility of high quality education resources. Survey found that India, Thailand, Vietnam, Malaysia, the Philippines, Indonesia, Brazil, Argentina, Chile, South Africa, Egypt and so on also have we can make use of and the introduction of a number of high-quality education resources. When choosing foreign education resources, not just rely on foreign certification as a result, because of this certification is the lowest standard, cannot reflect its real school quality and level, different areas and different types of colleges and universities in our country, economic and social development of awareness of foreign high-quality education resources, demand and diversity.

Practical Characteristics. In order to improve the quality of education and education, China has introduced education resources. The second is to cultivate international talents and promote the internationalization of education in China. The standard of quality education resources is changing with the needs of China's economic and social development. Must revolve around national talent, science and technology key projects and the implementation of the teaching program for children, priority basic subjects top students experimental program, excellent engineers, outstanding physicians and legal talent planning and national and local economic and social development in key areas are in urgent need of the shortage of professional disciplines.

Complementary Characteristics. The imported excellent education resources should be the "door to door" of our education institution or subject. We should give full consideration to the educational strength, level and characteristics of our educational institutions, so that the education resources of both sides can effectively match and complement each other.

Process Characteristics. The introduction of high-quality education resources is a whole process concept and the whole process of supervision. The introduction of high-quality education resources, one should strengthen the communication between the two sides and improve the execution of the agreement. It will take forcible measures to supervise the running subject to mobilize, integration of existing high quality education resources in China and the introduction of education resources complementary advantages, the advantages of high quality education resources into school characteristics and overall efficiency in education.

The Principle of Introducing High-quality Educational Resources to the program. Chinese-foreign cooperative program become the important way of internationalization of education or booster, ultimately depends on whether it can meet the demand of the country opening to the outside 
world, cultivate a large number of with international vision, familiar with international rules, to participate in international affairs and international competition of international talents.

\section{Establish the Guarantee Measures}

Establish and Improve the Working Mechanisms. Since the implementation of the education program outline, the number of Chinese-foreign cooperative program has increased and the number of Chinese-foreign cooperative program has increased. Declaration agency and currently, needs to be built in the early stages of the project evaluation and examination mechanism, strict, have proposed for us to Chinese-foreign cooperative program to carry on the strict censorship, supervise and urge its various related resources integration of the campus, for projects held by institutions or the top design, ready to straighten out the schools and colleges, the relationship between project and other aspects of the relationship. To attempt to establish the main body of the newly declared Chinese-foreign cooperatively-run school, if there are any existing projects, the system of the five year summary report of the project should be reported in the new project declaration material.

Adjust the Strategic Layout of Introducing High-quality Education Resources. Talents cultivation is cyclical and lag, to plan Chinese-foreign cooperative program in the long run to introduce high quality education resources, the disciplines and specialties of the layout and the regional layout, from a strategic height of encouraged, restricted or prohibited cooperative program disciplines and professional guidance, principle and requirements of local government at the provincial level according to the guiding principles to make the key introduction of disciplines and specialties of mid-term and long-term programs; The dynamic adjustment mechanism should be established according to the ever-changing needs of education, and timely policy adjustment. On the regional layout, overall consideration, improve the quality of Chinese-foreign cooperative program on the east coast, and cooperate with "western education revitalization plan", encourage and support the Midwest shortage of underdeveloped regions in the introduction of the local economic and social development of the high quality education resources. On the layout of colleges and universities, promote the "985 project" from the national strategic demand level in colleges and universities, aimed at the world famous high level research university, introduce high quality education resources, and protecting local institutions of higher learning initiative and enthusiasm of the Chinese-foreign cooperative program, to help them solve the practical difficulties and problems in the process of cooperative program, to encourage and support them closely to meet the needs of local economic and social development introducing themselves and adapt to the development goals of high quality education resources.

Adopting the Policy measures of Classification Management. The classification management of Chinese-foreign cooperative program is in line with the actual situation of China's national conditions and Chinese-foreign cooperative program, which is conducive to the scientific introduction of high-quality education resources. In reality, some school-running institutions have insufficient understanding of the legitimacy and policy boundaries of economic interests in Chinese-foreign cooperative program. The existing laws, regulations and policies for Chinese-foreign cooperative program and reasonable return for profit problem statement is not clear, in the implementation of the operation and standardize the hard, some regulations to meet the requirements of the World Trade Organization and other international organizations, with the Chinese government promised not to conform. Practice requirements as soon as possible for for-profit and nonprofit policy measures for classified management of the Chinese-foreign cooperative program, should adhere to the principle of using the same quality standards to regulate, further clarify the ministry of education and the management responsibilities of local government, to strengthen the regulation of non-profit project, make a clear definition of the non-profit orientation of Chinese-foreign cooperative program.

Exploring New Modes. In Chinese-foreign cooperative program, the introduction of high quality education resources should stick to the principle of ocean is convenient, in the process of combining the reality of education in our country and the development direction, a comprehensive understanding of the partner country education output policy, strengthen policy dialogue with the foreign cooperative program around the world; We will further improve the information system of foreign degrees and 
institutions. To assess the qualification and effectiveness of the education institutions that wish to cooperate with us, and to understand the status and level of these institutions in their respective countries; To play a role in the education department of the diplomatic and consular missions abroad, and strengthen its systematic construction of high-quality education resources research and dynamic information in the host country. At present, we should focus on the following problems: first, to unify and improve the understanding of the significance of the establishment of a branch office in China to explore foreign institutions of higher education. It is to allow foreign education institutions set up branches program in our country, its policy objectives must be very clear, that is not in order to solve the quantity problem of school-age youth enrollment and related education, but through this pattern or organizational system overall introducing overseas advanced educational philosophy, curriculum system, teaching methods and quality guarantee system, promote our country's higher education system and mechanism reform and talent training mode reform, up to the promotion of China's higher education quality demonstration leading role.

Implement the Go-out Project to Promote Quality Education. Resources, the introduction of initiative in colleges and universities to carry on the cooperative program of "going out" work, is to enhance our country's education system in the world of voice, to improve education in our country on the international fame and influence, the important measures to promote the internationalization of education in our country. For a deeper understanding of foreign education institutions of education in China, at the same time deepening our understanding of foreign education institutions and education information resources, to promote more foreign high-quality education resources has important significance to China's cooperative program. Which helps to our country and other countries in education, degree, the mutual recognition of credits and the interface on the quality certification system, strive for and developed countries in education, degree, on the mutual recognition of credits have greater breakthrough, so as to promote the further development of Chinese-foreign cooperative program. To develop characteristic and traditional culture of our country education benefit, revitalize and integrate domestic existing high quality education resources, improve the "going out" policy measures.

\section{Strengthen the Construction of High-quality Education Resources Support System}

Increase Investment in Chinese-foreign Cooperative Program and Strengthen the Financial Support for Introducing High-quality Education Resources. The relevant policies should be formulated to limit the proportion of school-running bodies to the tuition fees of the school institutions or projects; To promote the cost accounting of Chinese-foreign cooperative program, in order to eliminate waste of resources by auditing, monitoring and other means; Supervise running subject through internal fund-raising, and set up the fund allocation, social and other forms to carry out to the school where a Chinese-foreign cooperatively-run school and project funding.

Strength the High Quality Talent Pool and Strengthen the Talent Support. Science and introduce high quality education resources, must rely on a large number of knowledge of internationalization of education philosophy and theory of Chinese-foreign cooperative program, the solution of countries and regions education cooperative and exchange tasks and requirements, familiar with foreign education system, has the Chinese-foreign cooperative program daily management and practical operation ability, adapt to the new situation of Chinese-foreign cooperative program need management personnel and other professionals. The related to introduce high quality education resources granted transfer of knowledge and ability, the quality education into the training plan and teaching system, the provinces, autonomous regions and municipalities directly under the central government and education administrative department relevant personnel, international cooperative and exchanges in education institution of functional departments and related personnel education institutions concerned Chinese-foreign cooperative program in the actual workers training theory and practice.

Strengthen the Scientific Research and the Theoretical Support. The scientific research of Chinese-foreign cooperative program is the foundation for promoting the scientific development of Chinese-foreign cooperative program, and its development level is one of the important signs of the development of Chinese-foreign cooperative program. Chinese-foreign cooperative program to study 
important practical problems as the main direction, active service decisions, reverse the Chinese-foreign cooperative program study "in not, enough", give full play to the Chinese-foreign cooperative program research training and cultivating professional talents of Chinese-foreign cooperative program and management platform, provide professional support to introduce high quality education resources.

\section{Conclusions}

We will increase the support for training specialized personnel of high quality Chinese-foreign cooperative program. Xiamen university in the country take the lead in cultivating professional Chinese-foreign cooperative program of pedagogy research doctoral and master has been for many years, some other universities also carried out this work, but overall is still unable to meet the needs of the development of practice. We should encourage and support the establishment of a new discipline of Chinese-foreign cooperatively-run education, and cultivate the specialized talents needed for Chinese-foreign cooperative program in the form of education. Actively guide and promote to concentrate the power of study, to explore the common rules, service, innovation theory, the decision to guide the practice for the purpose of Chinese-foreign cooperative program nationwide academic community planning and construction work.

\section{Acknowledgements}

This work was supported by the Pilot project of comprehensive professional reform of International Economics and Trade (Joint Program, USU and NWUN) (Grant No:2017XJZYZHGGSD-01) and by Research project on education and teaching reform (Grant No:2017XJJG-12) of the Northwest Minzu University.

\section{References}

[1] Zhang Zongyuan, Research on the issue of educational property rights in China, Educational Exploration, 5(2010)5-11.

[2] Xia Jingtao, Study on the issue of educational sovereignty of Chinese and foreign cooperative education, Journal of Northeast Normal University (Philosophy Society Edition), 1 (2015 ) 3-9.

[3] Tang Zhentong, Education quality supervision mechanism of Sino foreign cooperative program, Educational Research, 2013, (12).

[4] Zhang Menghua, The distinction between educational property rights and educational sovereignty . Chinese Adult Education, 4 (2012)60-71.

[5] Mo Jane, Research on the predicament and Development Countermeasures of higher education in China, High Education Exploration, 3(2011) 12-20.

[6] Lin Yongbin, Research on the mode of running a school for higher education in China, Education and Teaching Forum, 2(2015)12-19.

[7] Linhui Lin, Specification, healthy, orderly, Professor about Chinese-foreign do learn, People's Daily, 2(2010)8-14. 